IIEy 22, 1934.

\title{
AQUARIULI CEMENT
}

It requires no: rgument to prove that a leaky aqu rium is a muisence to its omer end my be disastrous to its inmetes. This Letter Circular telis how to meke and use aquariun cement, ana gives more det iled instructions then vould be possible in an ordinary letter.

It is assumed thet the reader is to wake his own gquariun, frene wh all. This ocounts for the peregrepis concerning the str.neth: necessary. The primery object of the cenent is not to hold the aquariun togetner, but to prevent leakage. It can be teken for granted" that the manceturer of aquaria knows enough not to put ilinsy ones upon the miket.

The design and construction of the wetel frameworl of the aouriun must reflect the ingenuity and skill of the raker, but if the conposition of the cenent were left entirely to him, mithout any helprul subestions, he mi ht be at a loss to knom where to start. The three coments for witch formuse are given are known to be jood, no tiley till oo entiely setistectory if uroperly meade end used.

It will be sssumea throt the errine of the aquarium is made of metol. Altiough it rey rest on a wooden baso, the construation must be such that the cement will. not come into contact with the mood. If this should occur, the mood mil tend to draw the oil out of the cement, wich will then be slightly porous. The rasult mey be that noisture will ooze through to the rood end cause it to warp, and tizus place an undue strein uon tine whole aquatun and perhaps ruin it.

If an aquerum fillod with weter is pioked up and noved to another place, there is a ciance of sterting leaks, because the stresses. upon the freme are not distributed as evenly, nor in the

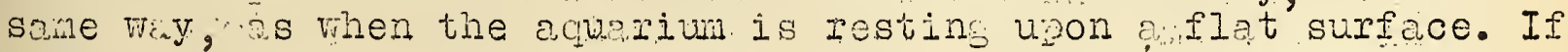
the freme is of very rieid construction, it mey ve lifted, but even then it is sefer to dip - not pour - out most of tire veter beforehand. For a I ge acuarium, e cheap "kitchen" table with casters is a convenient sujort, micin can be moved with litule effort. 
The freme should be so strong that the pressure of the water will not be able to spread. the sides apert. Strength without a heavy appearence of the frame is most easily secured by having a. strone metel trin around the top. This will not only hold the sides together, but it will also shield the upper edges of the glass panes, wilch wovid otherwise have to be ground smooth. If left rough they would be unsighty and dangerous. Miney would be pretty sure to cut the hands and chins of visiting small children, who alveys seize the top edge of the aquerium and look in over it.

The pressure against the sides is not a ntter of theory, but soiething very real. If an aguarium wich neasures 18 by 24 inches is filled to depti of 10 inches, it will contain 18.7 gal, or 155.810 , of water. The following simple calculation will give the total outward pressure against the four sides. The averafe depth is 5 inches, so each square inch of tine sides is, on the average, under tile pressure of $a$ colum of water 5 inches high. Tilis column of water, 5 cubic inches, weighs 0.1810 , beceure 1 gal, or 231 cubic inches, weichs $8.331 \%$. The total area of the sides in contact with the woter is $2 \times 10 \times 18+2 \times 10 \times 24=840$ squere inches; and $840 \times 0.18=151.21 \mathrm{~b}$, tine total outverd pressure grinst the sides.

An aquarium of nearly the seme cimensions as the one mentioned in the jrecedine perograph wes made witis a freme of angle brass 3/4" wide. The initered corners of the trin around the top were reinforced by soldering aditionel pieces of brass on the under side. After three or four years the steady pressure of the water broke the solder at one corner, and a bad leals started. This heppened twice more, when it was decided thet only riveting would make permanent repairs.

It would seen thet an aquarium of the size stated is about as large a one as can be we sefely with double-stirength window glass. Experience hes shom thet the pressure is not greet enough to burst the glass of an equariun of that size. Careful tests would no doubt show that the pressure could be greatly exceeded before the glass broke, but this does not necessarily mean that double-strength window. glass.: is safe to use in a larger aquariur. There should be a reasonable merein of safety. For this reason, single-strength wincow glass. Hea better not be used in even a very suall aquoriun, because it is so easily broken by blows. 
Chenging the proportions of the aquarius, and especiatly the depth of the water, even though its volume remeins the same, may make a serious difference in the oressure against the sides. For instance, a depth of 15 inches of water"in an aquariun 16 by 1 s. inches will make 1.8 .7 gal as before. "But now the avertge depth is $7 \mathrm{l} / 2$ inches, so the average jressure will be incrensed by onehali, or to 0.27 lb per square ilich. The total area or tire sides in contact mith the water will be $2 \times 15 \times 16+2 \times 15 \times 18=1020$, instead of 840 , square inches. Then, $1020 x 0.27=275.41 \mathrm{~b}$, the outward pressure. It would not seen' safe to expect anytining but plete glass to withstand this pressure. Fortunately for the good.

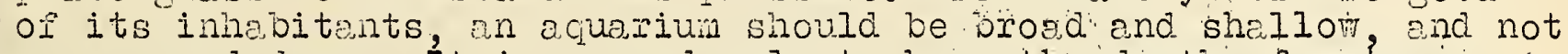
narrovi and deep. It is a good rule to have the deptin of water no greater than the width of the aquariur. If the depth is much less, down to a rersonoble winimum, so much the better.

Carefully measure the frane for the olass; and cut the latter as exactly as possible. It is best to make the ieasurements at the bottom of the Iraine, because the upright pieces at the corners may not all be vertical and perallel to ono onother. Especially if the frame is honemade, it is safest not to assune that opposite spaces are of the seme lengtin within, say, 1/16 incin.

Two pieces of gless, for opposite sides, con be practically the full length of the speces jito Wilcin they ere to go, or perhaps better, about $1 / 16$ inch shorter. The second peir of panes nust be shorter tinen the corresponding speces by the comined thicknesses of the first two with their leyers of cement. II the bottom of the aquariun is to be covered. with a piece of glass, decide when measurias whethor it will be put into place before or aster the sides. The dimensions of the pottom perie and the wiath or the side pones depend upon this decision.

An example will we the the precedine paragrajh olecrer. Suppose the acuarium frame riteasures 15 by 18 inches inside, and is 10 inches high. Ir the longer sides are to be glozed first, the pieces of glass must be only $1715 / 16$ inches lone; to ailow $1 / 16$ inch for clearance. The penes for the 15-inch spaces should be only $14 \mathrm{l} / 2$ inches in length, if the glass is double-strength, mich is a full eighth of an inch thiok, or even a trifle more. In adition to the combined thicknesses of the two long panes there will be two layers of cement, each not more than $1 / 8$ inch thicis, in all totaling $1 / 2$ inch, which leeves only the $141 / 2$ incines of space mentioned. 
If the botton pane is to be put in place before the sides, it should measure $1 / 16$ inch less than the space, or $1415 / 16$ by 17.15/16 inches. The sides will rest upon the potton pane and the layer of cenent under it. They should be only $93 / 4$ inches wide, so they will not project above the top of the irme. If the bottom piece of glass is to be put in last of all, it must measure not wore than $141 / 2$ by $171 / 2$ inches, or perhaps $1 / 16$ less each way, for a reason thet will appear iater. The side panes, which will rest directly upon the botton, cen be a full 10 inches in widtin.

The allowances stated in the example will have to be changed if the glass differs inuch frow $1 / 8$ inch in thickness. If the job heppens to be the glizing of a freme with grooves into which the slass slides, the measurements mst be made accordingly. It mey be seie to assune thet the spaces are the seme top and botton, but if there is any doubt, an accurete measurenent can be made st the bottom, witir the aid of two strips of wood that wizen placed end to end are a few inches longer than the side to be measured. One end of each stick must be silall enough to reach all the way into a groove. Hold the sticks in such a way that one end of ench is in eroove, while the other ends overlep. On one of the sticks mark where the end of the other stick coines. Nom lay then on a table in the same relative posioions and accurately measure the distance fron end to end. Cut the gless about $1 / 16$ inch less than the totel length just measured.

Sometines, for one reeson or other, a piece or glass vill be a shide too' long for tine space. The excess is too small to be cut off, but it.can be removed by neans of a coarse file. Lay the glass on a table, with its edje rojecting fraction of an inch. Then with cautious downerd strokes, with the file held at an cinle of about 45 degrees with the glass, bevel the edge of the latter." Turn the gloss over and repeat the process, and Iinelly square the edge with the file held vertically. The chies risir in this operation is not brecking the pane, but getting chips of glass in the eyes. Wear goggles, or shut the eyes at each stroke of the file, and keep children away. Another wethod, though more likely to break the glass, is to chip the edge with the help of one of tine slots of a gloss cutter.

Various mixtures of bituininous end tarry substances, knomn as "marine glue", are used for calkinf the seams of pontoons, and for other sinilar purposes, but are not comonly regarded as suitable for aquariun cement. They stay quite soft, and in hot weather have a decided teidency to run. The cement for an aquarium should have wore body than warine flue, so thet it will not flow when it is wam, nor be squeezed out by the steady pressura of the vater. It is of course possible to melre a bituinous cenent having the necessary properties, but to write a formula for one presupposes 
a full knowled of the properties of all the meterials that go into it. Those who wish to experiment with bituninous nixtures should bear in mind that some tarry meteriols contain highly poisonous orf anic compounds that are soluble in weter, and thet night injure the fisis in the aquarium.

In tilis connection it way be said that although the cenents recominded further on contein compounds of lecd, a metel that is c cumulative poison, in actual use the cements prove to be hamless. The oil or vernish used in maling them protects the lead. compounds rrom the dissolving action of the water.

The ceinent must not be too soft, and if it does not finslly set stone-herd, so wuch the better. Theserequirenents are met well enouch by the cenents for wich fornules are given furtier on. Each of them contains boiled linseed oil or varnish. In thin films on jass or metrl, both the oil and the vasnish should dry completely in a silort time. The drying is caused by chemical conbination with oxysen from the air, end though the first action is on tho surface of the film, the inner perts also soon become oxidized... The cement in an aquerum is in a thick layer, measuring inwards from the exposed edce, so it takes a very lons time for athospheric oxygen to diffuse a.ll though it and to harden it.

Cenents thet are soid to remin sort inderinitely cen be bought. The Bureeu has excmined none of them, and can express no opinion about then. The flexible cenents used for calking the joints of uissonry are nentioned for those who wish to experiment. To kee the cenent from bein forced out by the pressure of the water, it should have fine send mired with.it. These cenents are soid to be made of whiting cnd other pigments, vith blown rapeseed oil and possibly a little linseed oil.

The reason why the cenent should renein wore or iess yielding is thet glass and netals do not expand or contract at the pane rate when the temper ture chriges. However, the degree of softness needed is perheps exaggerated in tine winds of those who know the bare fect of tine exphsion, but have no idea of its inegintude. Take the etrene cese or an aduariun viti an alumin frane, and suppose it to be wormed from $70^{\circ}$ to $1.00^{\circ} \mathrm{F}$. For this $30^{\circ}$ rise in tempeteture, each inch of the frane nesured at the lower temperature will expend to 1.00039 inches and eachinch of the gylass will expand to 1.00015 inches. The difference, 0.00024 inch, is the amount tire cesent must yield. Tis mount is about equal to onesixth the thickness of an orain ry sheet of cellophene. If the acuriun frene is brass or iron, the corresponaing differefree is still less than for aluminum. It does not natter whether the aquarium is 10 inches or 10 feet in length, because the expansion takes place equelly over every runnine inch of a cemented joint. 
In this discussion it has been assuned that the rise in temperature is brought about by a waming up of the room in which the aqueriur is. The argunent pplies equaly well if the temperature drops.

The Bureau of Fisheries has for a long tine used an aquarium cenent mede by mixing 5 parts by weight of glazier's, putty vith 1 pert each of pordered litinige end red lead, and enoush boiled Iinseed oil to give the mixture the consistency of putty. The lithrge, and especially the red lead, hasten the setting of the cement, but even so it is advisable to add a fen drops of japan drier to the boiled oil. If slete-colored cenent is desired, add a little lemplack. Tinis is most easily done by mixine it with the dry porders, but in thet case it is hard to tell just how much will be needed to give the cenent the desired color. The nixed dry fjlers are of a lighter color thn the finished cement. The materials for this and the other cenents con be bought in beint stores.

National

The/Burceu of Standerds is not officielly concerned with aqurid, though cements fall within its province. However, nembers of its staff constructed aquerid at home, and sone of theri have used a cement for winch the formula is given in various books. In this formula all parts are by bulk, not by weight, as follows: iuix 10 parts each of plaster of peris, fine sand and litharge, I pert of powdered rosin, and enough boiled linseed oil to make a stiff putty. If possible, the sand should be so fine tinat all of it vill pass through a No. 60 sieve. Coarse sand "will' mike a gritty cenent that is ind to work. Powdered puinice cari be used if really fine sand. can not be obtained.

A variant of this formula is perlieps an improvenent upon the original. The plaster is omitted, red lead replaces about $1 / 3$ of the lithorce, and spar varnish is used instead of boiled linseed. oil. This cement is tackier then the ore made with linseed oil, and for that reason is inerder to work with.

None of the formulas need to be slavishly followed, provided. the ingredients are thoroughly mixed and the resulting putty is neither so stiff that it con not be aplied smoothly with a puttywnife, nor so soft that it will tend to flow, end will also take too many days to set.

The Bureau has been asked how to noke aquariun cenent of different colors. Those who ere sufficiently interested hay experiment with the formala of the Buredu of Fisheries, replacing part of the litharge and all of the red lead by puint pigments of the desired colors. 
The cenent can be made nost easily. on a piece of sheet netal or a pene of glass. Mix the dry materials thoroughly, then ad the oil, or varnish, a Iittle at sime, aid tork in each portion with a. putty-kilie. At one stage tile nixture will seem hopelessiy Iumpy, but this is a sign thet the end is appowching, and thet only a little more oil will be heeded." The portions added should be sialler tion before nd the working wore thorough because kneading meses the mass softer, up to a certain point. If the merk is overstepped, a litie hor of the dry materinls must be eded. If putty is used in the cenent, spreed it out in a thin layer, plece the dry neterials upon it, and proceed in the wey just describéd.

It is not possiole to calculate closely what weight: of the dry insredients will be needed to mare enough cenent ifor an acuriun of a "given size, "vecause the "bulking value" or volume occupied by a given weifht oI e powder, depends not only upon the actual density of the incividus particles, but also upon their size snd won how closely they are pecked tozetici. ordinarily the aị spaces in tifitly packed hass of a fine powaer total a sreater volume then thet of the solia particles. Another thing to renember is thet when a Ine and a corise powder are mixed, say one cuisc incil of esch, there vill be less thei two cubic inches of the mixture, because the fine jerticles enter the larger spaces between the coarse particles. The oil or vornish used in the cenent not only fills tie air spees, but it also coets tile perticles and keeps them fron ecturily touchino

one must be content with neline a rough estinete of the volume of cenent that will be needea. If the frome nas a pase $18 .$. by 24 inches and tire verticel ance-pieces are 12 inches hich there 111 be $8 x 12+2 x 18+2 x 24=180$ mnning inches of neta to be cenented for the sides. If the glass overlops the netel $1 / 2$ inch, this mill medin $1 / 2 \times 180=90$ squere inclies to ve covered. Final1y, if the layer of cenent is lis jnch thiot, iliere vill be recuired $1 / 8$ x $90=11.2$ cubic incies of ceinent. A peine of glass on the bottom mecns an additions 84 runilis incies, or 5.2 cubic inches of cement. The totol, 14.6 cuoic indhes, is apout 0.5.pint, Iiquid weasure. It wolld not be wise to ifirureas closely as tis in buying the meterials or in wixing the cenent. Ine insredients are so cheap thet one can afford to hoke consichably iore cenent as a margin of safety in cise of Histeres.

Before struting to ut" in the gless, it" is advisable to make ready severil slender strijs of mood, to hold the panes under gentle pressure against tire cenent. ihey should be a littie longè tinan tine distance between oposite penes, so that they inust be bent slightly when set in place. They will thus exert a steady pressure that will keep the glass from falling invard. The jressure should not be so erent as to force out any great anount of the cenent. If this should occur, the strips of wood are too lons and stiff, the cenent is too soft, or too much of it has been pplied. 
Judgrnent must be exercised in preparing aind using the rooden strips, so that they will do their work nost safely ond efiectively. No fixed sule cri be laid down lor lengths and thicknesses that vili be right for an aqueium of any particular size. At least four will be heeded for each tro pieces of glass, but is the panes are much over a foot in length it is advisable to use two or three nore. Do not set any of the strips close to the corners, but 4 or 5 inches away, hemsured alons the diagonels of the panes. If more than four are used, space elli of then in such a way thot the pressure will be as even as possible over the whole area. If a discarded inner tube is conveniently at hand little squares cut from it are useful to keep the ends of the stidrs from slipping on the glass.

With a puty-knife aply a smooth, thin leyer of centent to the parts of the wetel freme ageinst winch the two full-size penes are to go. Set. these panes in ploce and press then gently with outspread ingers so as to melie periect contact between glass and cenent. There should be no large air bubbles trapped in between, and especially no it chrnels thot extend across tine layer of ceisent. If the cemont is carefully sinootied rinen applied and is made thinner towards the odge of the metel, the chance of trapping air will be lessened. If ovorything looks satisfactory; hold the panes in ploce by means or wooden strips. Next, cement the rest of the frane, insert the last two pieces of glass and hold then vith strips.

Unless tise botton of the aquariun is mode of slate, it is desirable to cover it with a pane of gless, wich can be insorted either before or aiter the sides are in place. If after, a piece oi stiff wire bent at a right ancle at the end can be used as a hook to let it cown gently, . beceuse the cleerance vill be too sinel for the ingers. In either case the pane on the bottonmust be cemented, just as the sides are. It mould be extremely difficult, if not impossible, to cement evenly tie entire bottom of the met 1 frame, yet the glass siould be supported in the midale, or the weight of water will bend, ond may break, it. Fortuntely it will suffice to plece litite debs of cencht here and there over the pottom of the aquerium. These, with the layer of cenent around its edges, wil suport the gless a fraction of an inch above the metal botton. In the 10 by 24 -inch acuariun thet has been mentioned, the bottom is of gelvaized iron resting flat upon a table, and the glass thet covers it is double-strength windon glass. Is there is no teble nor a strong netal botton, plate glass or a slab of sipte, should be used for an aquarium of that size. 
If the glass for: the bottom is the last piece to be inserted, the strips of wood must be removed temporarily, but they should be replaced prompty. Then.clean off any excess of cenent, smooth its exposed edges, and give the job a close inspection. Look especially for air chonnels, and if there are any, close them by working in cement with. the putty-knife, andif, possible, from the inside of the aciueriura.

If everything seems to be right, leave the equarium untouched for at lesst 24 hours. By that time the pressure of the sticks will probsbly heve forced out a little cement from the joints. Remove this with the putty-knife, or with a scroper mede of a small square of sheet met. l. While doing this, on the outside op the aquarium, be careful not to push too. hard egeinst the glass, lest the cenent be loosened.

After cinother 24 hours, repeat the inspection. Little if any more cement should he, ve been squeezed out, unless it was entixely too soft at the st rt, or the oil hapens to be slom-drying. If the cenent seans to be herd enough. clean the glass surfaces by scrubbing them gentry with powdered punice or non-scratching cleanine powder, on a piece of wet rago: Renove all loose bits of cewent.

By this time the average builder of an equerium vili find it difficult to resist che temptetion to fill it vith vater. It will be safe to do so, as a rule. The sticks can now be removed. The filled aquariun should be left clone for notb a day or two to make sure that there are no slow leaks. If there are any large oponings in the cement, water will come tinrough then as soon as the aquarium is rilled. In that case all tize vater must be taken out, and the aquariun be wiped dry inside and out. Then, after the crevice has had time to dry out, close it by vorking cenent into it, from the inside of the acuariun. The cement for this purpose cain be a little soiter then chet used at first, to mise it go into the narrow space nore easily.

There may be one or wore tiny leaks through wich the weter slowly oozes. Indeed, it has been said that a new aquarium alvays lea.ss. $:$ ljttle. It is usuelly possible to stop such leaks without taking out the water. Get c little of the stiffest clay that can be found (for instence, "bell clay"), moisten it and worls it in the hnds. Then ply 3 ittle or it over each leak, on the inside of tile aquariun. It will be washed awey gradually, but enough of it will be lest to fill tire noles and stop the leaks. The same trestment con be siven to leeks thet sometimes st It after the aqueriun has been in use for months. 
It is recomended, though the advice is not based upon the results of experiments, not to put plants and ish in the rirst weter with inch the aquarin is ililed. At least it hes the best chances of ali to become contanineted with lead.

The Burenu of Fisheries, Depertment of Comerce, Wasington, D.C., should be ejplied to for informetion obout fish and aquatic plants, and the wintenance of the aquarium. Those who live near Iarge public libreries con find various books and wegezines oin aquariun fishes. Anone the autrors of books wose nones will be

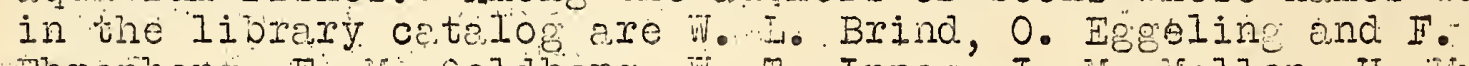

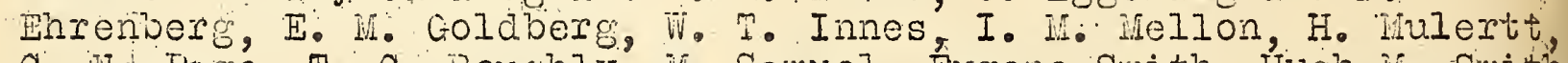
C. I. Page, T. C. Roughly, ir. Somul, Eugene Sinth, Hugh i. Swith,

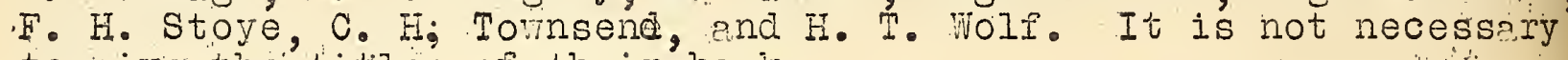
to give the titles of their books.

A simple device for aereting an aquariun is described in Science, vol. 77, pp. 565-6, June 9, 1933. It oan be used where running" water anc a drain-pipe are not, available. other aerating devices, run by electric wotors, are on the market, Electric heaters, wost of them with temperature control (themostats), as well o cenents and other materis for making aquaria, can be bought. Nunerous advertisements are to be found in the ma.gazines. 

